Tjalling C. Koopmans Research Institute Thllizh Roopmanes

Discussion Paper Series nr: 13-01

\title{
A Barrier Options Approach to Modeling Project Failure: The Case of Hydrogen Fuel Infrastructure
}

Ye Li

Peter Jan Engelen

Clemens Kool 


\section{Tjalling C. Koopmans Research Institute Utrecht School of Economics Utrecht University}

Kriekenpitplein 21-22

3584 EC Utrecht

The Netherlands

telephone $\quad+31302539800$

fax +31302537373

website www.koopmansinstitute.uu.nl

The Tjalling C. Koopmans Institute is the research institute and research school of Utrecht School of Economics.

It was founded in 2003, and named after Professor Tjalling C. Koopmans, Dutch-born Nobel Prize laureate in economics of 1975.

In the discussion papers series the Koopmans Institute publishes results of ongoing research for early dissemination of research results, and to enhance discussion with colleagues.

Please send any comments and suggestions on the Koopmans institute, or this series to J.M.vanDort@uu.nl

ontwerp voorblad: WRIK Utrecht

\section{How to reach the authors \\ Ye Li \\ Peter Jan Engelen\# \\ Clemens Kool \\ Utrecht University \\ Utrecht School of Economics \\ Kriekenpitplein 21-22 \\ 3584 TC Utrecht \\ The Netherlands. \\ E-mail: c.j.m.kool@uu.nl \\ \# RODEO Research Centre \\ Belgium}

This paper can be downloaded at: http://

www.uu.nl/rebo/economie/discussionpapers 
Utrecht School of Economics

Tjalling C. Koopmans Research Institute

Discussion Paper Series 13-01

\title{
A Barrier Options Approach to Modeling Project Failure: The Case of Hydrogen Fuel Infrastructure
}

\author{
Ye Lia \\ Peter Jan Engelen ${ }^{\mathrm{ab}}$ \\ Clemens Koola \\ aUtrecht School of Economics \\ Utrecht University \\ ${ }^{\mathrm{b}}$ RODEO Research Centre
}

December 2012

\begin{abstract}
In this paper, we contribute to the literature by including a knock-out barrier option in a compound real option model to take account of immediate project failure, a socalled sudden death. We apply the model to the case of hydrogen infrastructure development. In our case study, we find that even for the least conservative valuation method no profitable business case can be made for the development of hydrogen as a sustainable transportation mode. However, we do provide some suggestive scenarios that plausible tax schedules can be designed to overcome the starting problems for hydrogen infrastructure development. To the extent that sudden project failure would be predominantly caused by potential reversals in political support, a cheap way to make the development of hydrogen infrastructure and other similar projects - more attractive would be to design credible long-term political commitments to this type of development.
\end{abstract}

Keywords: Uncertainty, real option, barrier option, investment failure, hydrogen infrastructure investment.

JEL classification: G32, O32, Q42. 


\section{Introduction}

Over the past decades, real option modeling has become an increasingly popular approach for the valuation of large infrastructural projects as well as the valuation of innovative projects in technologyintensive industries. Examples of the former include applications to toll road development (Rose, 1998 and Wooldridge et al., 2002), airport expansion (Smit, 2003), highway development (Zhao et al., 2004), high-speed rail development in Taiwan (Bowe and Lee, 2004), hydropower investment in Norway (Kjærland, 2007), and hydrogen infrastructure development (van Benthem et al., 2006). Examples that apply real option valuation to innovative projects in technology-intensive industries can be found in Cassimon et al. (2004, 2011a), Jägle (1999), Newton and Pearson (1994) and. Schwartz (2004). McGrath and Nerkar (2004) provide empirical evidence that real option theory can be effectively used to value $R \& D$ investment strategies in the pharmaceutical industry. Real option valuation is preferable to net present value computations because it takes into account the value of waiting and operational flexibility: even with a negative NPV now, the project still may be profitable at a later point in time. Put differently, NPV may tend to undervalue a project.

Typically, real option valuation is based on the hypothesis that the underlying project value changes over time according to some stochastic process with high volatility. The only uncertainty taken into account is the possibility of a deviation from an expected condition based on the variation of one or more environmental conditions that drive the stochastic process. Standard option models assume that the option stays alive irrespective of the value of underlying asset during the life time of the option. However, some investment projects may have knock-out features that may immediately and completely terminate the model between two decision points. Here, one may think of a physical catastrophe causing the loss of crucial societal and/or governmental support, insurmountable technological problems, or unexpected extra costs requiring additional funding at excessive prices. Less dramatically, governments or regulators may cancel or cut the funding if technological progress stays below their expectations; or investors may abandon their plans when an unplanned event causes a very low expected present value of the underlying investment because they do not want to spend additional money up till the moment of the next decision point to proceed or not to the next phase. A real-world example of such termination is a pilot project for hydrogen-fueled buses in the Amsterdam public transport system. After its start in 2008 it encountered an operational problem: a hydrogen leakage between the recently delivered hydrogen tank and the hydrogen refueling system was detected due to the misfit of two cables. The project has been suspended since then (Backhaus and Bunzeck, 2010). Failure to account for such knock-out characteristics may lead standard real option models to overvalue a project. 
To cope with the possibility of permanent project failure, Schwartz and Moon (2000) develop a real option model which incorporates a Poisson process to evaluate R\&D projects with a chance of a catastrophic event that causes the project's value to jump to zero. They solve the ensuing valuation problem by numerical approximation. Cassimon et al. (2011b) use discrete success-failure probabilities at each stage of the project to reflect technical catastrophic failure in a compound option framework. However, so far no completely satisfactory solution has been found for incorporating catastrophic events. In this paper, we extend the existing real option literature by including a (downand-out) barrier into a real option framework to value a large and innovative infrastructure project. We will develop and present a model to estimate the fair value of an innovation project that will be knocked out if at any time the underlying project value reaches the minimum level that is acceptable to investors.

Options with barrier features are quite common in the financial option literature. The original pricing formula for continuously monitored knock-out barrier options goes back to Merton (1973). Recently, financial options with barriers have been frequently used to analyze a firm's default probabilities (see Broadie et al., 1997; Brockman and Turtle, 2003; and Kou, 2003). The basic idea is that corporate equity cannot be modeled as a standard path-independent call option on the value of the firm. It will always be in the interest of the equity holder - that is, the holder of the option on the firm's residual value - to hold on to the option until expiration. However, before expiration the bondholders may pull the plug and declare bankruptcy if firm assets drop to a critically low value. Consequently, it is argued that equity should be modeled as a path-dependent option that can be terminated prior to expiration. A similar reasoning applies to the real option approach of valuing large and innovative infrastructure projects. Cost overruns, financial distress, extra funding needs, or the breakthrough of a competing technology can lead to an immediate termination of the project prior to expiration of the option and the next decision moment. This is particularly important for project financing. To the best of our knowledge, we are the first paper to apply barrier options in a real investment setting.

We will apply our barrier approach to the case of hydrogen infrastructure development. In our view, the hydrogen case is not only an appropriate application of a barrier model but it is also of relevance in its own right. From a societal perspective, the search for a feasible and sustainable source of energy to reduce the emission of greenhouse gasses has increasing priority and hydrogen is one of the most attractive alternatives known so far (Adamson and Pearson, 2000). We focus on the development of a hydrogen fuel station network for cars. For a successful transition to hydrogen-powered transportation one needs to solve crucial technology difficulties, create a market for new vehicle types, and further achieve economies of scale in vehicle production. An innovation such as hydrogen fuel-cell technology will only have a chance to be successful if it is perceived to be safe, reach an equal performance as a regular internal-combustion-engine vehicle today, and the supporting infrastructure 
for refueling is established (Schulte et al., 2004). The latter requires significant amounts of irreversible investments over a decade or more until large-scale commercialization can be reached (Schoots et al., 2010). In short, investing in a new hydrogen infrastructure will face huge market risks as well as technological risks and a substantial probability of intermediate failure and abandonment.

So far, energy analysis in general and hydrogen analysis in particular mostly uses sensitivity analyses, scenario studies or simulations to assess the impact of specific uncertainties. Many hydrogen infrastructure development reports adopt scenario-based simulations, for instance, HyWays ${ }^{1}$, the U.S. Department of Energy Roadmap ${ }^{2}$ and HITA $^{3}$. Moreover, a number of studies (Agnolucci, 2007; Chang et al., 2007; Joffe et al., 2004) have analyzed and compared the performance of different hydrogen pathways. Thomas et al. (1998) evaluate different market penetration scenarios to estimate the likely number of fuel cell vehicles which might be sold in the United States over the next decades. Ogden (1999a) develops an infrastructure case study for hydrogen-fueled vehicles in Southern California. Mulder et al. (2007) make use of a top-down penetration scenario to assess different technology configurations in terms of chain efficiency and $\mathrm{CO}_{2}$ emissions. A similar research is conducted by Wietschel et al. (2006) to evaluate hydrogen technologies under different costs, emissions and efficiency scenarios. Clearly, it is preferable to use a more accurate capital budgeting decision-making framework such as real option modeling. It can directly transform uncertainties into flexibilities and provide more insight in the dynamics of the project (Guerrero, 2007, Lander and Pinches, 1998). Real options are now widely accepted in the literature to value and select projects with strategic issues and operational flexibilities (Dixit and Pindyck, 1994; Trigeorgis, 2000). To our knowledge, van Benthem et al. (2006) is the only real option application on hydrogen.

For our basic model, we use a compound option framework, which captures the various transitional phases of the development of a hydrogen-based transportation system. We model market and technological uncertainty as a two-dimensional Brownian motion with both market and technological uncertainties rolling together for an increased volatility. ${ }^{4}$ In addition, we impose a barrier which will work as a restriction to the stochastic process and may cause it to stop earlier. This is particular useful, as investing in green energy is subject to resource constraints (limited capital, limited ability to borrow) and to competition of other alternative investments for funding. In the analysis, we compare the model's outcomes with and without the barrier. Finally, we explicitly take into account different

\footnotetext{
${ }^{1}$ HyWays is a research project conducted by the European Commission with the aim of developing a validated and well-accepted roadmap for the introduction of hydrogen in the energy system in Europe. More details can be found at www.hyways.de.

${ }^{2}$ See also http://hydrogendoedev.nrel.gov/roadmaps_vision.html.

${ }^{3}$ Hydrogen Infrastructure Transition Analysis by the U.S. National Renewable Energy Laboratory (NREL). See for more information: www.nrel.gov.

${ }^{4}$ Cortazar et al. (2001) use a similar approach to evaluate natural resource exploration investments with price and geological-technical uncertainty, but without a barrier as a restriction to the stochastic process.
} 
scenarios with respect to political support (subsidies) necessary for a successful roll-out of a hydrogenbased transportation system.

In our case study, we find that even for the least conservative valuation method no profitable business case can be made for the development of hydrogen as a sustainable transportation mode. However, we do provide some suggestive scenarios that show that plausible tax schedules can be designed to overcome the starting problems for hydrogen infrastructure development. To the extent that sudden project failure would be predominantly caused by potential reversals in political support, a cheap way to make the development of hydrogen infrastructure - and other similar projects - more attractive would be to design credible long-term political commitments to this type of development.

The rest of the paper is organized as follows. Section 2 introduces the concept of investment failure and its relation with barrier options. In Section 3 we present the basic model and discuss its main features. Next, Section 4 introduces the case of hydrogen infrastructure investment and presents the case results when applying the model. Finally, section 5 summarizes and concludes.

\section{The possibility of default in large-scale infrastructure projects}

Large-scale infrastructure projects are risky as they require huge irreversible investments, have a long planning horizon, and often use a non-standard technology. Consequently, such projects often experience cost overruns or benefit shortfalls and unforeseen difficulties. For a sample of 258 transportation infrastructure projects Flyvberg (2007b) shows that the frequency of cost escalation for a randomly selected project is $86 \%$, with an average cost escalation of about $28 \%$. The size of the standard deviations of the cost escalation (between 30 and 60\%) illustrates furthermore the huge uncertainty with respect to cost overruns. Revenue overestimation occurs frequently as well. For instance, Flyvbjerg, Skamris Holm and Buhl (2005) find that rail passenger forecasts are overestimated by an average of $105 \%$. Examples of projects hit by cost overruns and benefit shortfalls abound: Boston's Big Dig, the Channel tunnel, the Quebec Olympic stadium, Toronto's Sky Dome, the Sydney Opera House, London's Millennium Dome, Hannover's Expo 2000, Athens' 2004 Olympics, the Copenhagen metro, the Oresund Bridge between Sweden and Denmark, and the Great Belt rail tunnel linking Scandinavia with continental Europe (Flyvbjerg, 2007a). Moreover, since it is quite difficult to specify ex ante the relevant risks of large-scale projects, such projects are vulnerable to unforeseen events (Szyliowicz and Goetz, 1995).

For the above reasons, many large infrastructure projects have experienced situations of financial distress. Examples include large-scale projects such as Eurotunnel, Iridium, Globalstar, Bangkok's Skytrain or Canary Wharf (Esty, 2004). A detailed case study on the financial distress of the 
Eurotunnel project can be found in Vilanova (2006). Miller and Lessard (2000) show that about $40 \%$ of large-scale engineering projects between 1980 and 2000 performed poorly, leading to total abandonment or restructuring after financial distress. It is no surprise to see that such risky projects are often separated from the parent company to prevent a failing project to spill over to the rest of the company (Esty, 2004). Such stand-alone entities are often highly leveraged making them even more vulnerable to delays, cost overruns and unplanned events. Obviously, knowledge of the project default level is crucial in determining the economic viability of the infrastructure project. As the energy sector attracts more project financing than any other sector, our model and our case study on energy innovations is very relevant for both companies as well as policy makers.

Figure 1: The decision-making diagram of a barrier real option

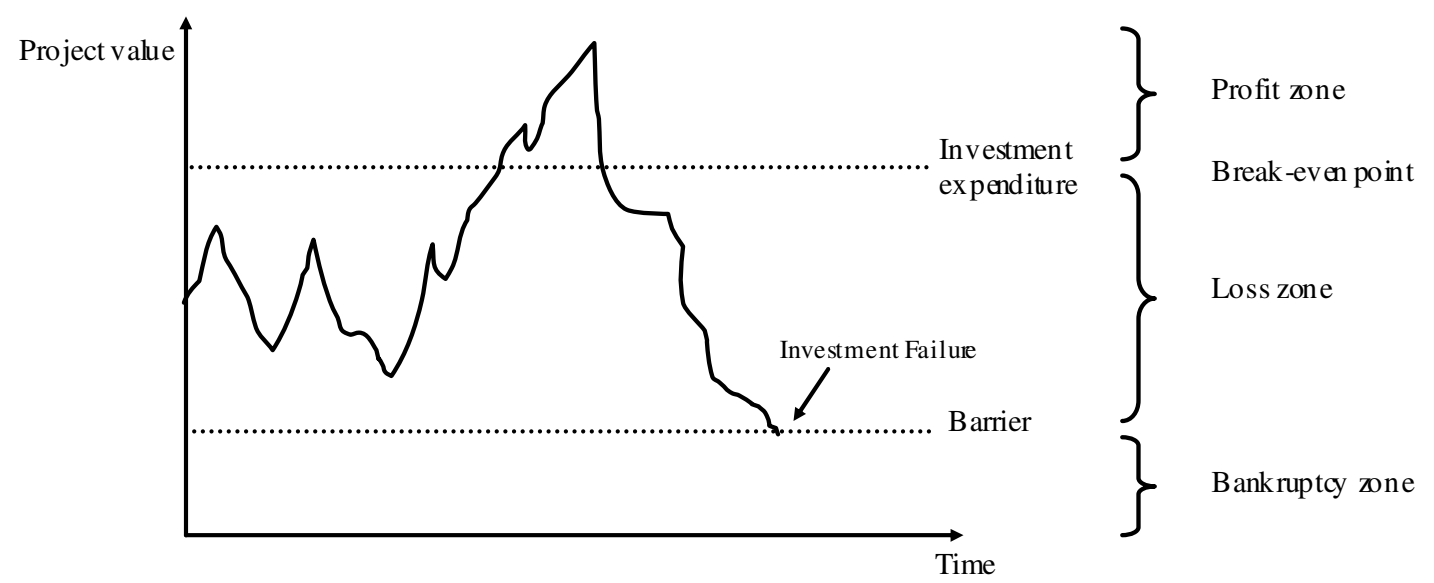

In the literature on default risk, structural models postulate that default occurs when the value of a firm's assets drops below the debt value. For instance, Duffee (1999) uses a contingent claims valuation to support this assertion and to find the probability of default. In a similar way, large infrastructure projects might also get bankrupt if the economic value of the project drops below a certain threshold value. Figure 1 illustrates this process by depicting a possible path of the project value over time. When the project value increases over and above the investment expenditure, the option to invest in the project is in-the-money and calls for (early) exercising the investment option. We label this the profit zone in Figure 1. When the project value stays below the investment expenditure the option to invest is out-of-the-money. In this case investing in the project is lossmaking, but the company holds on to its option as the project might become profitable in the future (loss zone).

When the project value drops below a certain threshold value or barrier, default occurs and the entire project is abandoned. We label this the bankruptcy zone in Figure 1. Default may be due to market reasons, for instance, when the project cannot service its interest and debt payments anymore or when 
the project cannot find additional financial resources to cover its cost overruns. For instance, at the moment of the financial distress of the Eurotunnel project in 1995, its project value amounted to $£$ 3,59 million, while its outstanding debt was equal to $£ 6,35$ million (Schueler, 2007). Other reasons for hitting the barrier include technological failure, breakthrough of a competing technology or political interference. Real option valuation of a project that is characterized by a knock-out feature can be done with a down-and-out barrier option. The project - and the option - is immediately terminated if the underlying asset value reaches a specified barrier level prior to the expiration date of the option. We will first develop the barrier option model and then apply it to the hydrogen infrastructure case.

\section{The Model}

\subsection{Theoretical framework}

Investing in the infrastructure project will result in a series of future cash flows. We assume that the evolution of the underlying project value can be written as a Brownian motion $\left\{V_{t}\right\}_{t \in[0, T]}$. The uncertainty is defined in a filtered probability space $(\Omega, F, \mathrm{P})$, where $\Omega$ includes all possible instants of the stochastic variation of $V_{t}$. Given the information filtration $F$, the market value of a claim on the expected future cash flows is represented by $V_{t}$ under physical probability measure $\mathrm{P}$ at time $t$. We assume the market to be complete with no transactions costs. The risky investment project $d V_{t}$ will follow the stochastic process:

$d V_{t}=\mu V_{t} d t+\sigma_{M} V_{t} d W_{t}^{M}+\sigma_{T} V_{t} d W_{t}^{T}$

with $\mu$ the expected rate of return on the project, $\sigma_{M}$ the market uncertainty, $\sigma_{T}$ the technological uncertainty, $d W_{t}^{M}$ and $d W_{t}^{T}$ stochastic variables which follow a Wiener Process in which $d W_{t}^{j} \sim N(0, \sqrt{d t})$ for $j=M, T$.

The complexity of the model can be reduced by collapsing market uncertainty and technological uncertainty into one factor with volatility $\tilde{\sigma}$. Formally, the combined volatility is defined as

$\tilde{\sigma}=\sqrt{\sigma_{M}^{2}+2 \rho \sigma_{M} \sigma_{T}+\sigma_{T}^{2}}$. Total volatility depends on the degree of market and technological uncertainty and on the correlation $\rho$ between these two sources of stochastic shocks. $\tilde{\sigma}$ is higher when market uncertainty $\sigma_{M}$ and technological uncertainty $\sigma_{T}$ are positively correlated, for instance when market acceptance (demand) goes up as technological advances occur. It is lower when they are negatively correlated. In the simplified model, $d V_{t}$ will follow simple Brownian motion: 
$d V_{t}=\mu V_{t} d t+\tilde{\sigma} V_{t} d W_{t}^{M T}$

\subsection{Option valuation}

We first present the option valuation model for a simple real barrier option, before incorporating the barrier into a compound real option framework.

\subsubsection{European barrier option}

The value of barrier options is calculated path dependently with trigger prices. Assume a call option with maturity time $T$ and strike price $I$ has zero value if the underlying project value $V_{t}$ falls below the barrier $B$ at some point before maturity. Then the option value at any time $t$ can be written as:

$C(t, V)=e^{-r(T-t)} E^{Q}\left[\left(V_{T}-I\right)^{+} 1_{\left\{\max _{0 \leq \leqslant \leq T} V_{t} \geq B\right\}}\right]$

Here, $E^{Q}$ denotes the expectation under the risk neutral measure $Q,\left(V_{T}-I\right)^{+}$is short-hand for $\max \left[\left(V_{T}-I\right), 0\right]$ and $1_{\left\{\max _{0 \leq \leqslant \leq T} V_{t} \geq B\right\}}$ is an indicator function that takes the value 1 when the underlying project value $V$ does not fall below the barrier $B$ during the lifetime of the option and the value 0 when it does. The barrier $B$ is the minimum level of the underlying project value that is acceptable to investors.

We assume that $C \in[(0, T) \times(B, \infty)]$, that $C$ is continuously differentiable in the first variable and twice continuously differentiable in the second variable and satisfies the partial differential equation

$\frac{\partial C(t, V)}{\partial t}=r C(t, V)-r V \frac{\partial C(t, V)}{\partial V}-\frac{1}{2} \tilde{\sigma}^{2} V^{2} \frac{\partial^{2} C(t, V)}{\partial V^{2}}$

We define $\beta=\frac{B}{V_{0}}<1$, where the parameter $\beta$ reflects the size of the barrier relative to the initial underlying project value. Extra boundary conditions are determined by the nature of the barrier. Failure occurs at the first time $t$, where $t \in[0, T]$, at which the project value $V_{t}$ fails to reach the level $B$. If so, we assume the option expires without value ${ }^{5}$ :

$C(t, B)=0, \quad 0 \leq t<T$,

In case the project value remains above the barrier $B$ during the whole lifetime of the option, the end value of $\mathrm{C}$ is equal to:

$C(T, V)=\left(V_{T}-I\right)^{+}, \quad B \leq V_{t}, \beta \leq 1$

\footnotetext{
${ }^{5}$ There might also be situations where the project will have some scrap value upon default. In that case the model incorporates a non-zero payoff $\mathrm{R}$.
} 
The probability of an investment failure is defined as the chance at time $t$ that the underlying project value falls below the barrier before option maturity T. Based on Brockman and Turtle (2003), this probability can be written as:

$P_{t}\left(V_{T} \leq B\right)=\Phi\left(\frac{\ln (\beta)-\left(r-\frac{1}{2} \tilde{\sigma}^{2}\right)(T-t)}{\tilde{\sigma} \sqrt{T-t}}\right)+\beta^{\frac{2 r}{\sigma^{2}-1}} \Phi\left(\frac{\ln (\beta)+\left(r-\frac{1}{2} \tilde{\sigma}^{2}\right)(T-t)}{\tilde{\sigma} \sqrt{T-t}}\right)$

Note that the probability in equation [7] is increasing in the horizon considered, since it is a cumulative probability of reaching the barrier before $T$ at current time $t$. Note that as $V_{t}$ becomes large, the likelihood of the barrier being activated becomes negligible. ${ }^{6}$

To derive the option value, based on the formula for a European down-and-out call option proposed by Broadie et al. (1997), we need the solution of the heat equation [8] with the initial condition $A(0, x)=F\left(e^{x}\right)$. $^{7}$

$$
A(\tau, x)=\frac{1}{\sqrt{2 \pi}} \int_{-\infty}^{\infty} F\left(e^{x+\sigma \sqrt{\tau} \xi}\right) e^{-\frac{1}{2} \xi^{2}} d \xi
$$

Then:

$C(t, V)=V\left[N\left(d_{1}\right)-\beta^{\frac{2 r}{\tau^{2}}+1} \cdot N\left(d_{3}\right)\right]-I \cdot e^{-r(T-t)}\left[N\left(d_{2}\right)-\beta^{\frac{2 r}{\tau^{2}}-1} \cdot N\left(d_{4}\right)\right]$

where

$$
\begin{aligned}
& d_{1}=\frac{\ln \left(\frac{V}{I}\right)+\left(r+\frac{1}{2} \tilde{\sigma}^{2}\right)(T-t)}{\tilde{\sigma} \sqrt{T-t}}, d_{2}=d_{1}-\tilde{\sigma} \sqrt{T-t}, \\
& d_{3}=d_{1}+\frac{2}{\tilde{\sigma} \sqrt{T-t}} \ln (\beta), d_{4}=d_{2}+\frac{2}{\tilde{\sigma} \sqrt{T-t}} \ln (\beta) .
\end{aligned}
$$

\subsubsection{Compound barrier options}

Multi-stage investments can be seen as a sequence of real options and thus modeled as an $n$-fold compound option. For an investment project with three phases (I, II and III), as we will use in our case study, the pilot phase I has a strategic value as it gives the option to move to phase II in case of success, which in itself gives the option to move to phase III. Figure 2 contains a graphical illustration.

\footnotetext{
${ }^{6}$ Many models on credit default (e.g. Reisz and Perlich, 2007) also include a second probability that the asset price is between $B$ and $I$, i.e. $B \leq V_{T}<\mathrm{I}$.

${ }^{7}$ Appendix A contains the detailed proof.
} 
Figure 2: A three-phased investment plan as a compound option

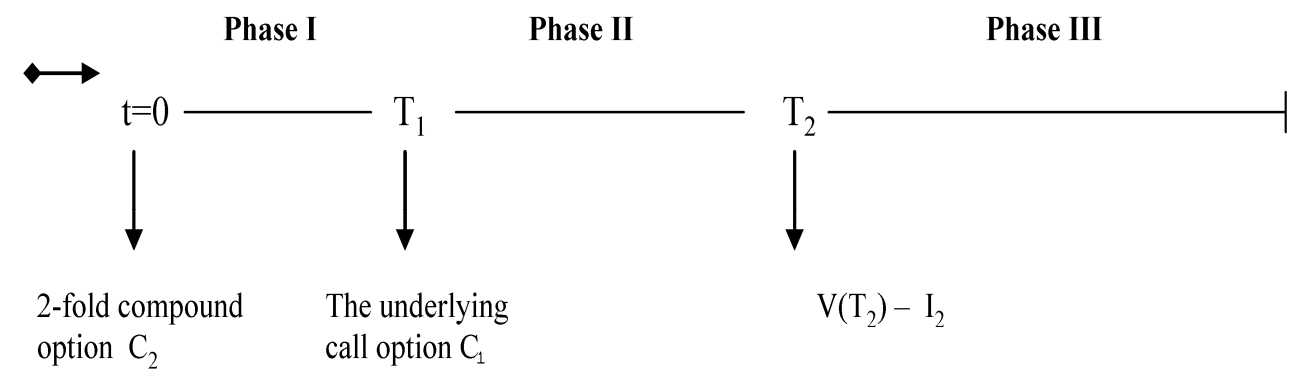

The start of phase I indicates the opportunity to subsequently invest in two optional phases towards the full commercialization of the fuel station network. ${ }^{8}$ The strategic value of this opportunity can be captured by a 2-fold compound option given by:

$$
\begin{gathered}
C_{2}(t, V)=V\left[N\left(a_{1}, a_{2} ; \sqrt{\frac{T_{1}}{T_{2}}}\right)-\left(\frac{B}{V}\right)^{\frac{2 r}{\sigma^{2}+1}} N\left(c_{1}, c_{2} ; \sqrt{\frac{T_{1}}{T_{2}}}\right)\right]-I_{2} e^{-r\left(T_{2}-t\right)}\left[N\left(b_{1}, b_{2} ; \sqrt{\frac{T_{1}}{T_{2}}}\right)-\right. \\
\left.-\left(\frac{B}{V}\right)^{\frac{2 r}{\tilde{\sigma}^{2}+1}} N\left(d_{1}, d_{2} ; \sqrt{\frac{T_{1}}{T_{2}}}\right)\right]-I_{1} e^{-r\left(T_{1}-t\right)}\left[N\left(b_{1}\right)-\left(\frac{B}{V}\right)^{\frac{2 r}{\tilde{\sigma}^{2}+1}} N\left(d_{1}\right)\right]
\end{gathered}
$$

where $C_{2}$ is the value of the compound option with the notations

$$
\begin{aligned}
& a_{1}=\frac{\ln \left[\frac{V}{V^{*}}\right]+\left(r+\frac{1}{2} \tilde{\sigma}^{2}\right)\left(T_{1}-t\right)}{\tilde{\sigma} \sqrt{T_{1}-t}}, \quad a_{2}=\frac{\ln \left[\frac{V}{I_{2}}\right]+\left(r+\frac{1}{2} \tilde{\sigma}^{2}\right)\left(T_{2}-t\right)}{\tilde{\sigma} \sqrt{T_{2}-t}}, \\
& b_{1}=a_{1}-\tilde{\sigma} \sqrt{T_{1}-t}, b_{2}=a_{2}-\tilde{\sigma} \sqrt{T_{2}-t}, c_{1}=a_{1}+\frac{2}{\tilde{\sigma} \sqrt{T_{1}-t}} \ln \left[\frac{B}{V}\right], c_{2}=a_{2}+\frac{2}{\tilde{\sigma} \sqrt{T_{2}-t}} \ln \left[\frac{B}{V}\right], \\
& d_{1}=b_{1}+\frac{2}{\tilde{\sigma} \sqrt{T_{1}-t}} \ln \left[\frac{B}{V}\right], d_{2}=b_{2}+\frac{2}{\tilde{\sigma} \sqrt{T_{2}-t}} \ln \left[\frac{B}{V}\right] .
\end{aligned}
$$

In this model $T_{1}$ is the maturity date of the first option. At time $T_{1}$, the compound option gives the right to buy another option $\mathrm{C}_{1}$, the underlying option, that has an exercise price of $I_{2}$ and a maturity date $T_{2} . V^{*}$ is the value that the underlying option $\mathrm{C}_{2}$ is at the money at time $T_{1}$, i.e., $V\left(T_{1}\right)=V^{*}$. The solution of $V^{*}$ solves the underlying call option $C_{1}\left(T_{1}\right)-I_{1}=0$. For this multi-stage investment to successfully move to investment phase III, the boundary condition that $V\left(T_{2}\right)>I_{2}$ given that $C_{1}\left(T_{1}\right)>I_{1}$ and $V_{t} \geq B$ needs to be fulfilled. It follows in a straightforward way that

\footnotetext{
${ }^{8}$ It is straightforward to extend the model to more phases.
} 
the value of the compound call option $C_{2}$ depends on the joint probability that the project value is above $V^{*}$ at $T_{1}$ and above $I_{2}$ at $T_{2}$, conditional on staying above barrier $B$ during the two optional phases.

\section{Case Study}

This section applies the compound barrier option model to the case of technological innovation in hydrogen fuel-stations in the Netherlands. First, we provide some background information and describe the business case. Next, we give an overview of the input numbers and cash flow calculations before moving to the valuation through the compound barrier option framework.

\subsection{Description of the hydrogen infrastructure project}

According to the International Energy Agency, the transportation sector in 2009 consumed nearly 56\% of global oil production and was responsible for around 50\% of all airborne emissions (IEA, 2010). The combination of diminishing fossil energy resources, environmental pollution, and climate change urgently calls for a sustainable transport system. Unlike fossil fuel, hydrogen does not emit carbondioxide, which can substantially reduce emissions of regulated pollutants and green houses gases (Ekdunge and Råberg, 1998; Gasafi et al., 2008). Being powered directly from hydrogen-oxygen reaction, fuel cell vehicles can achieve a high level of system efficiency in an extremely quiet operation process with zero tailpipe emissions (Smit et al., 2007). Sandy Thomas (2009) compares the societal benefits of deploying various alternative transportation solutions, including hybrid electric vehicles and all-electric vehicles powered by either batteries or fuel cells, leading him to conclude that a hydrogen powered fuel cell vehicle is the best option to reduce greenhouse gases. Mercuri et al. (2002) estimate that replacing 5\% of diesel buses in Milan with hydrogen fuel cell buses can reduce health care costs by $€ 1.37$ million per year.

As an energy carrier, hydrogen cannot be directly extracted like natural gas or oil. Just as electricity, it has to be produced from a primary source and transmitted to the location of consumption. Consequently, existing transport infrastructures need to be upgraded to supply hydrogen fuel cell vehicles. This requires significant amounts of irreversible investment costs over a decade or more until large-scale commercialization can be reached. With a long maturity time, profitability is most likely to be delayed until a sufficient number of hydrogen-powered vehicles can be produced and accepted by consumer markets. The significant initial costs, together with the project uncertainty, will probably result in insufficient cash inflows to justify investment based on any traditional economic model such as a cost-benefit or a NPV model. Based on the environmental and economic issues discussed, it is 
widely believed among practitioners that additional strategies and incentives are required to accelerate the transition.

A hydrogen energy chain starts with hydrogen production, followed by hydrogen transport and distribution and finally hydrogen conversion and end use. The costs of a hydrogen infrastructure vary with different types of hydrogen production technologies, forms of storage and methods of transportation and dispensing. Most of the infrastructure cost will be spent on building a large network of refueling stations. We consider the most likely case where relatively large-scale centralized hydrogen production plants produce hydrogen, which will then have to be transported and distributed to the fuelling stations. Liquefied hydrogen will be transported by using tanker trucks; the cost of which is incorporated in the production cost.

Our case study is based on the HyWays (2008) scenario. Hydrogen-based vehicle rollout in Netherlands is expected to happen in three phases: a pre-commercial phase from 2010 to approximately 2014 comprised of technology refinement and market preparation. About 30 hydrogen stations will be set up to serve around 1000 cars. The early-commercialization phase II (2015-2024) requires the construction of additional fuelling stations up to a total of 100 stations serving approximately 5000 fuel cell vehicles. Finally, in the full-commercialization phase III (2025-2044) approximately 20,000 hydrogen vehicles will be on the road. Under this scenario around $40 \%$ of the population will have local access to hydrogen fuelling stations. It takes approximately 350 hydrogen refilling stations and is equal to approximately $7 \%$ of the total number of fueling stations national wide.

In the remainder of this section, we will conceptualize the initial investment as creating growth options and we develop a framework for the valuation process. We follow the HyWays scenario and assume that investment in a hydrogen infrastructure will take place in several phases, moving gradually from small scale fleet projects to a large distribution network coverage. The value of such staged investments is not only determined by the cash flows coming from the initial investment but also by the future investment opportunities opened up by the pilot stage. Each stage can be viewed as an option on the value of subsequent stages and valued as a compound option (Cassimon et al, 2004). It is important to note that Phase III (full-commercialization) cannot proceed without the execution and successful completion of Phase II, which itself will only take place upon the successful transition from Phase I. The end points of Phases I and II thus represent decision times. A positive continuation decision at that time requires the option value of the future project to exceed the extra investment required to enter the next phase. If not, the project will be terminated. In addition, default in the early stages is possible between formal decision moments when the project value drops below the barrier. In that case, the entire project will be directly terminated. 


\subsection{Overview of the input parameters and cash flow calculations}

To calculate the expected operating cash flows for each project phase, we need to estimate the present value of the expected operating revenues $\mathrm{R}_{\mathrm{t}}$ less operating expenses $\mathrm{C}_{\mathrm{t}}$ :

$$
R_{t}=\sum_{t=1}^{T} F_{t} \cdot \partial \cdot X_{t} \cdot H_{t} \cdot e^{-r t} \text { and } C_{t}=\sum_{t=1}^{T}\left(F_{t} \cdot \partial \cdot X_{t} \cdot C U_{t}+I_{t} \cdot M+C L_{t}\right) e^{-r t}
$$

with $T$ the estimated economic lifetime of the infrastructure, $F$ the number of hydrogen fuel cell vehicles on the road, $\partial$ the fuel efficiency in $\mathrm{kg}$ per $\mathrm{km}, X_{t}$ the estimated annual travel distance in $\mathrm{km}$ per vehicle, $H$ the hydrogen retail fuel price per $\mathrm{kg}$ (pre fuel tax), $C U_{t}$ the variable hydrogen production costs , $M$ the fixed operational and maintenance costs per year expressed as a percentage of the investment cost $I_{t}$ (the construction costs of the fuel stations), $C L_{t}$ the average labor cost per year and $r$ the risk-adjusted discount rate. ${ }^{9}$

Figure 3 gives an overview of the input values of all parameters of our cash flow model. ${ }^{10}$ To calculate hydrogen demand for fuel cell passenger vehicles, we assume that each vehicle will use approximately $0.7 \mathrm{~kg}$ of hydrogen each day (CaFCP, 2008). For an average fuel cell vehicle with a fuel economy of 80 to 96 kilometer per $\mathrm{kg}$, this would accommodate about 56 to 64 kilometer of driving on an average day (Ogden, 1999b; CaFCP, 2008). During the full commercialization phase with approximately 20,000 fuel cell vehicles on the roads, this corresponds to a total hydrogen fuel demand of $5,11 \times 10^{6}$ $\mathrm{kg}$ per year. For hydrogen fuel to be competitive with fossil fuels, the literature generally assumes a retail price of $€ 10 / \mathrm{kg}$ (van Benthem al., 2006). ${ }^{11}$ Although hydrogen is much cheaper produced from natural gas, the production process is always associated with the emission of greenhouse gases and local pollutants (Haryanto et al., 2005). Sustainable hydrogen cost is initially about $€ 5 / \mathrm{kg}$, but due to technical learning, we assume it will decrease to a long-term production cost of $€ 2 / \mathrm{kg}$ during the full commercialization phase (van Benthem al., 2006). This includes all the relevant expenses, for instance, transportation to the refilling station and carbon capture and storage (CCS) costs if necessary. All the numbers in Figure 3 are expressed in 2010 euros and are adjusted for inflation in the cash flow calculations. For these computations, we use a 25.5\% marginal tax rate (KPMG, 2011), an average eurozone inflation rate of $2.24 \%$ (ECB, 2011), a $21.21 \%$ net working capital requirement in a given year (as percentage of the sales) (Damodaran, 2011) and a straight-line depreciation over the 20 year economic life of each station. We use a risk adjusted discount rate of $8 \%$ for calculating the NPV of the project cash flows. ${ }^{12}$

\footnotetext{
${ }^{9}$ The full structure of the cash flow model is graphically presented in appendix B.

${ }^{10}$ Where necessary, we use secondary sources to determine appropriate parameters for this case.

${ }^{11}$ We take into account the regular fuel taxes in the Netherlands such as excise duty and VAT, which lowers the net retail price to $€ 4 / \mathrm{kg}$.

${ }^{12}$ This cost of capital corresponds to the 2010 sector averages of oil and gas distribution (7.19\%), environmental (7.62\%), natural gas $(8.07 \%)$, power $(8.23 \%)$, automotive $(8.58 \%)$ and chemical $(8.88 \%)$. Numbers are taken from Damodaran (2011).
} 
Figure 3. Overview of the hydrogen infrastructure case study with main input parameters

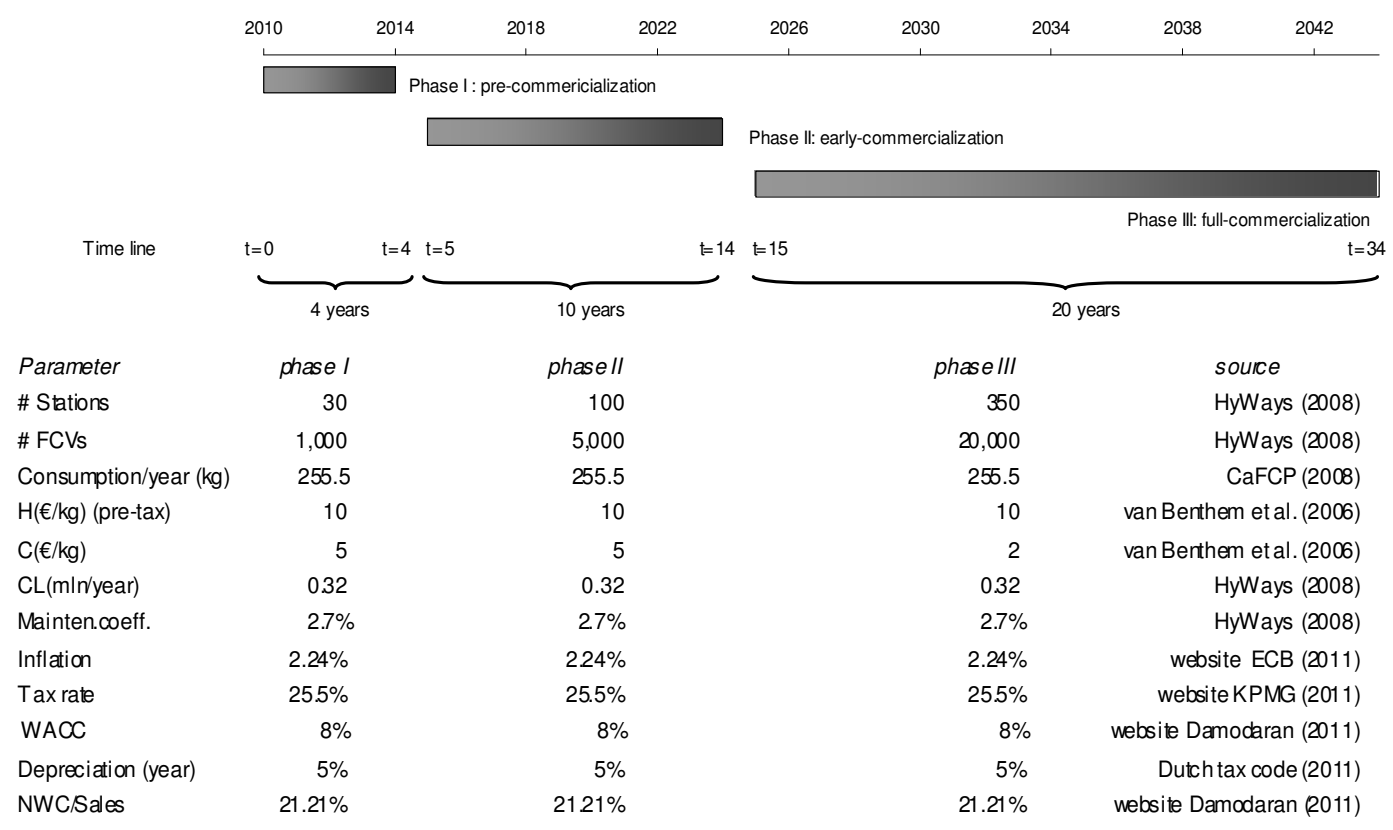

Each stage also requires investments in the necessary amount of hydrogen fuel stations in order to operate the fuel network. The cost of a hydrogen fuel station depends upon many factors, including the type of station, location, equipment manufacturing volume and continuing technology advancements. In the case study, we use the CGH2 fuel station type from the HyWays project with a unit cost of approximately $€ 0.49$ million. We assume unit investment costs can decrease over time as a result of economies of scale and learning. To reflect this, we specify the cost function as $\varpi(N)=\alpha \cdot N^{-b}$, where $\varpi(N)$ is the investment cost of the $N^{\text {th }}$ unit, $b$ is a learning parameter and $\alpha$ the investment cost of the first unit ( $€ 0.49$ million). The average investment cost to build $\mathrm{N}$ fuel stations will therefore be equal to $I=a \cdot \int_{1}^{N} N^{-b} d N$. To simplify calculations, the construction costs are assumed to occur at the beginning of each phase: $€ 12.52$ million for the first phase in year 2010 , €26.01 million for the second phase in 2014 and $€ 85.22$ million for the third phase in 2024. 
Table 1 Project's Cash Flows (in €mln)

\begin{tabular}{|c|ccc|cc|cc|}
\hline & \multicolumn{3}{|c|}{ NPV (2010) } & \multicolumn{2}{c|}{ NPV (2014) } & \multicolumn{2}{|c|}{ NPV (2024) } \\
\hline $\begin{array}{c}\text { Phase I } \\
(2010-2014)\end{array}$ & $-14,31$ & $-12,52$ & $-1,78$ & & & \\
\hline $\begin{array}{c}\text { Phase II } \\
(2014-2024)\end{array}$ & $-26,85$ & $-19,12$ & $-7,73$ & $-26,01$ & $-10,52$ & & \\
\hline $\begin{array}{c}\text { Phase III } \\
(2024-2044)\end{array}$ & $-16,42$ & $-29,02$ & 13,27 & & & $-85,22$ & 38,97 \\
\hline Total & $\mathbf{- 5 6 , 9 0}$ & $\mathbf{- 6 0 , 6 6}$ & $\mathbf{3 , 0 9}$ & & & & \\
\hline
\end{tabular}

Table 1 gives a concise overview of the project's cash flows. ${ }^{13}$ The construction costs in the subsequent phases strongly rise due to the increasing number of fueling stations to be built, from 30 in phase I, to 100 in phase II and 350 in phase III. The gradual reduction in the unit production costs only provides some moderation of the total investment required. Net operational cash flows remain negative in phases I and II and only turn positive in phase III. Even phase III as a stand-alone project is unprofitable, however. In NPV terms in 2024, required investment is $€ 85.22$ million while expected net cash from 2024 till 2044 flows - conditional on the available information in 2010 - only equal $€ 38.97$ million. We find a $-€ 14.31$ million NPV for phase I as a stand-alone project and a $-€ 56.90$ million NPV for the entire three phase project. Based on an NPV framework, the project will be clearly rejected. Even the pilot phase will not be started. That is, from an NPV point of view, no feasible business case exists for the development of a hydrogen-based transportation system in the Netherlands, despite the societal desirability of a more sustainable transportation system in the future. Put differently, according to our computations a minimum government subsidy of $€ 14.31$ million would be required for the pilot to start.

The next section analyzes the same business case from a real option framework and will provide additional insights into the flexibility of a phased investment project. It will show under what conditions each phase will default and under what conditions investment in the pilot phase will be triggered.

\footnotetext{
${ }^{13}$ A more detailed overview of the cash flow calculations is available from the authors on request.
} 


\subsection{Option Valuation}

We start our real option valuation using the parameters from Figure 3 that were also used for the NPV computation. Investing in pilot phase I opens up the possibility for two sequential follow-up phases II and III. The option on this sequential option can be seen as a 2-fold compound option. A compound option model requires the input of the investment costs per phase $\left(I_{1}, I_{2}\right.$ and $\left.I_{3}\right)$, the present value of the expected cash flows upon full-commercialization $\left(\mathrm{V}_{0}\right)$, and an estimate of the volatility of the project return $(\tilde{\sigma})$. As we combine the compound option framework with a barrier option, our model also requires the input of the barrier $(B)$. In this section, we propose benchmark parameter values for B and $\tilde{\sigma}$ as well as investigate to what extent variation in these parameters influences the results.

As exemplified by equation [2], our model collapses market and technological uncertainty into one volatility metric $(\tilde{\sigma})$. We propose to use available market data to provide a plausible estimate of this overall volatility. To this purpose, we select four listed small-cap firms and use the average of their stock price volatility as a proxy for our project volatility. The chosen firms are Hydrogenics Corp, Ballard Power Systems Inc, Fuel Cell Energy Inc and Plug Power Inc respectively. ${ }^{14}$ They have been selected because (a) they are active in the segment of hydrogen fuel cells and hydrogen fuel stations, (b) they are comparable in size to our project, (c) as small-caps their stock returns should reflect shocks to their firm value more accurately than would be the case for larger, more diversified firms and (d) their standard deviation in firm value should reflect the impact of both market and technological risk. Based on the daily stock returns over the period 2005-2009, adjusted for dividends and stock splits, we obtain an average annual project volatility of $66.75 \%$, assuming 250 trading days per year. ${ }^{15} 16$

Finally, we need to determine the level of the barrier. Using a data set of 7,787 firm-years on a diverse set of industrial firms, Brockman and Turtle (2003) find an implied barrier of about $70 \%$ for the total sample. However, different barriers have been suggested in the literature. For example, firms with high asset variability or high financial leverage can be expected to have a relatively high probability of hitting the barrier before the expiration date of the real option. This reflects the different position and trade-offs between debt-holders and shareholders. Debt-holders can have an incentive to enforce bankruptcy of the project before the next phase or decision point has been reached. Wong and Choi (2009) find that the median firm has a default barrier at around $74 \%$ of its liabilities. Given that project

\footnotetext{
${ }^{14}$ We refer to Appendix $\mathrm{C}$ for more qualitative and quantitative details about these firms.

${ }^{15}$ We follow the approach of Damodaran (2011) and assume that the standard deviation of debt is one-third of the standard deviation of equity and that the correlation between stock and bond prices is 0.30 .

${ }^{16}$ Compared to industry averages for 2010 our project volatility estimate is higher than the averages of oil and gas distribution (37.77\%), natural gas (38.29\%), automotive $(46.72 \%)$ and power $(56.52 \%)$ and of similar magnitude as chemicals (66.53\%) and environmental (67.65\%). See Damodaran (2011).
} 
companies have an average debt-to-total capitalization ratio of $70 \%$ (Esty, 2004), this would imply a barrier of $51.8 \%$ in our application.

In our analysis, we therefore use both a $50 \%$ barrier and a $70 \%$ barrier $\mathrm{B}$ of the project value and compare it to the benchmark no-barrier real option model. Using Table 1, the barriers then equal 6.64 million and $€ 9.29$ million, respectively. If the project value drops below this value before reaching the next phase investors will pull the plug and terminate the project. When we plug the above parameters in our compound barrier option model, we obtain the results as presented in Table 2.

Table 2. Project valuation for different barriers

\begin{tabular}{|l|r|r|r|r|r|r|r|}
\hline Scenario & $\mathrm{V}_{0}$ & Barrier & \multicolumn{1}{l|}{$\begin{array}{l}\text { NPV } \\
\text { project }\end{array}$} & NPV rule & $\begin{array}{l}\text { Value } \\
\text { Compound } \\
\text { Option }\end{array}$ & $\begin{array}{l}\text { Required } \\
\text { investment } \\
\text { Phase I }\end{array}$ & $\begin{array}{l}\text { Real option } \\
\text { rule }\end{array}$ \\
\hline No barrier & 13.27 & 0 & -56.9 & Reject & 11.11 & 14.31 & Reject \\
\hline $\mathrm{B}=50 \% \mathrm{~V}_{0}$ & 13.27 & 6.64 & -56.9 & Reject & 7.86 & 14.31 & Reject \\
\hline $\mathrm{B}=70 \% \mathrm{~V}_{0}$ & 13.27 & 9.29 & -56.9 & Reject & 4.37 & 14.31 & Reject \\
\hline
\end{tabular}

Legend: All numbers in million euros, except retail price. The pre-tax retail price equals $€ 10$ in all scenarios.

The corresponding after-tax retail price equals $€ 4$. Project volatility is assumed to equal $66.75 \%$ on an annual basis.

All three option models reject the investment, similar to the NPV rule. However, while the NPV rule shows a significant negative NPV value of $€-56.9$ million, the no-barrier option has a value of $€ 11.11$ million, short only about $€ 3$ million of the acceptance threshold. Here, the threshold is equal to the investment cost required for the pilot phase I of the project ( $€ 14.31$ million, see Table 1 ). ${ }^{17}$ Obviously, the follow-up potential of phases II and III is insufficient to justify investment in phase I.

The impact of imposing a barrier is also clear from the table. Imposing a $50 \%$ barrier reduces the option value to $€ 7.86$ million and a $70 \%$ to $€ 4.37$ million. The barrier makes the project increasingly unattractive, corresponding to the higher likelihood of abrupt and permanent knock-out. Applying equation [7], it follows straightforwardly that the probability of hitting the 50\% barrier prior to the full implementation phase equals $19 \%$ and of hitting the $70 \%$ barrier even $54 \%$. With a high probability of project default, the upside potential of phase II and III is too small to induce firms to invest in the pilot phase necessary to develop a hydrogen fueling station network. Note that our result confirms the general message in the literature that hydrogen as a sustainable transportation mode needs government support for initial take-off (Schulte et al., 2004; Murthy et al, 2011).

Subsequently, we analyze to what extent financial government support may turn the infrastructure project into a profitable business case, inducing firms to invest in the pilot phase. Naturally, the

\footnotetext{
${ }^{17}$ In our real option computations, we add the NPV of negative operational cash flows in phases I and II to the required investment at the start of each phase for simplicity.
} 
government has many instruments at its disposal to provide stimulus to the private sector in starting off the pilot phase of the project, such as for example providing a lump-sum subsidy, becoming a subordinated investor in the project itself or granting various transitory or permanent tax exemptions. Here, we limit ourselves for illustrative purposes to varying degrees of excise duty discounts. Moreover, we assume the benefits of these discounts accrue to the producer rather than the consumer as the consumer retail price is assumed to remain constant. Alternative scenarios are possible.

In the base case of Table 2, a pre-tax retail price of $€ 10$ per $\mathrm{kg}$ of hydrogen corresponded to an aftertax retail price of $€ 4$ per $\mathrm{kg}$. The $60 \%$ fuel tax burden is of similar magnitude as of fossil fuel and consists of a combination of excise duties and VAT. Under a similar fuel tax regime as fossil fuel both the NPV and the real option model reject investment in the infrastructure project. We consider discounts of 25, 50, 75 and 100 percent of the excise duties on fuel. In Table 3, we demonstrate the effect of these discounts on the attractiveness of the project. Note that both $\mathrm{V}_{0}$ and the required investment in phase I depend on the tax regime. In the latter case, this results from the fact that we add the operational cash flows from phase I to the investment costs for simplicity. With lower taxes, these cash flows become slightly less negative and thus reduce the required investment in phase I.

Table 3. Project valuation with fiscal subsidy (discount on excise duties)

\begin{tabular}{|c|c|c|c|c|c|c|c|c|}
\hline Tax scenario & $\begin{array}{l}\text { After-tax } \\
\text { retail } \\
\text { price }\end{array}$ & $\mathrm{V}_{0}$ & Barrier & $\begin{array}{l}\text { NPV } \\
\text { project }\end{array}$ & $\begin{array}{l}\text { NPV } \\
\text { rule }\end{array}$ & $\begin{array}{l}\text { Option } \\
\text { Value }\end{array}$ & $\begin{array}{l}\text { Required } \\
\text { investment } \\
\text { Phase I }\end{array}$ & $\begin{array}{l}\text { Real } \\
\text { option } \\
\text { rule }\end{array}$ \\
\hline \multicolumn{9}{|c|}{ No barrier } \\
\hline $25 \%$ discount & 5.1 & 26.38 & 0 & -39.8 & Reject & 23.25 & 13.92 & Accept I \\
\hline $50 \%$ discount & 6.2 & 39.50 & 0 & -22.6 & Reject & 35.66 & 13.53 & Accept I \\
\hline $75 \%$ discount & 7.3 & 52.61 & 0 & -5.5 & Reject & 48.20 & 13.13 & Accept I \\
\hline $100 \%$ discount & 8.4 & 65.73 & 0 & +11.7 & Accept & 60.84 & 12.74 & Accept I \\
\hline \multicolumn{9}{|c|}{$50 \%$ barrier } \\
\hline $25 \%$ discount & 5.1 & 26.38 & 13.19 & -39.8 & Reject & 11.30 & 13.92 & Reject \\
\hline $50 \%$ discount & 6.2 & 39.50 & 19.75 & -22.6 & Reject & 16.26 & 13.53 & Accept I \\
\hline $75 \%$ discount & 7.3 & 52.61 & 26.31 & -5.5 & Reject & 24.05 & 13.13 & Accept I \\
\hline $100 \%$ discount & 8.4 & 65.73 & 32.87 & +11.7 & Accept & 40.94 & 12.74 & Accept I \\
\hline \multicolumn{9}{|c|}{$70 \%$ barrier } \\
\hline $25 \%$ discount & 5.1 & 26.38 & 18.47 & -39.8 & Reject & 8.79 & 13.92 & Reject \\
\hline $50 \%$ discount & 6.2 & 39.50 & 27.65 & -22.6 & Reject & 12.27 & 13.53 & Reject \\
\hline $75 \%$ discount & 7.3 & 52.61 & 36.83 & -5.5 & Reject & 17.73 & 13.13 & Accept I \\
\hline $100 \%$ discount & 8.4 & 65.73 & 46.01 & +11.7 & Accept & 28.63 & 12.74 & Accept I \\
\hline
\end{tabular}

Legend: All numbers in million euros, except retail price. The pre-tax retail price equals $€ 10$ in all scenarios. Project volatility is assumed to equal $66.75 \%$ on an annual basis. 
The differences between the NPV framework and the three real option model become quite prevalent now: under the NPV rule, the project only turns profitable when no excise duty is imposed at all. The real option framework shows a more favorable trade-off. Without a barrier, a 25 percent discount is quite sufficient to make investment in the pilot phase attractive. If the barrier equals 50 percent, the project is still rejected at a 25 percent excise discount, but easily accepted at a 50 percent discount. Finally, with a 70 percent barrier, a 50 percent discount is not sufficient but a 75 percent is. Overall, the computations suggest tax incentives can be structured in a way to sufficiently support the development of a hydrogen infrastructure.

Finally, we turn to the role of project volatility. Generally, in standard real option models higher volatility implies a higher option value as the probability of ending in the money increases. However, in the case of a barrier there is a countervailing force: higher volatility raises the probability of hitting the barrier and seeing the project fail permanently. Figure 4 demonstrates the effect of different project volatilities on the compound option value for barrier levels B of 50\% and 70\%, respectively, compared to the no barrier benchmark case. Generally the lower the barrier and the lower the project volatility the stronger the positive link between project volatility and option value. In the range of plausible project volatilities, the negative effect of hitting the barrier roughly offsets the positive effect of higher potential values. Overall option values appear relatively insensitive to changes in project volatility in this range.

Figure 4: Effect barrier level on option value and total volatility

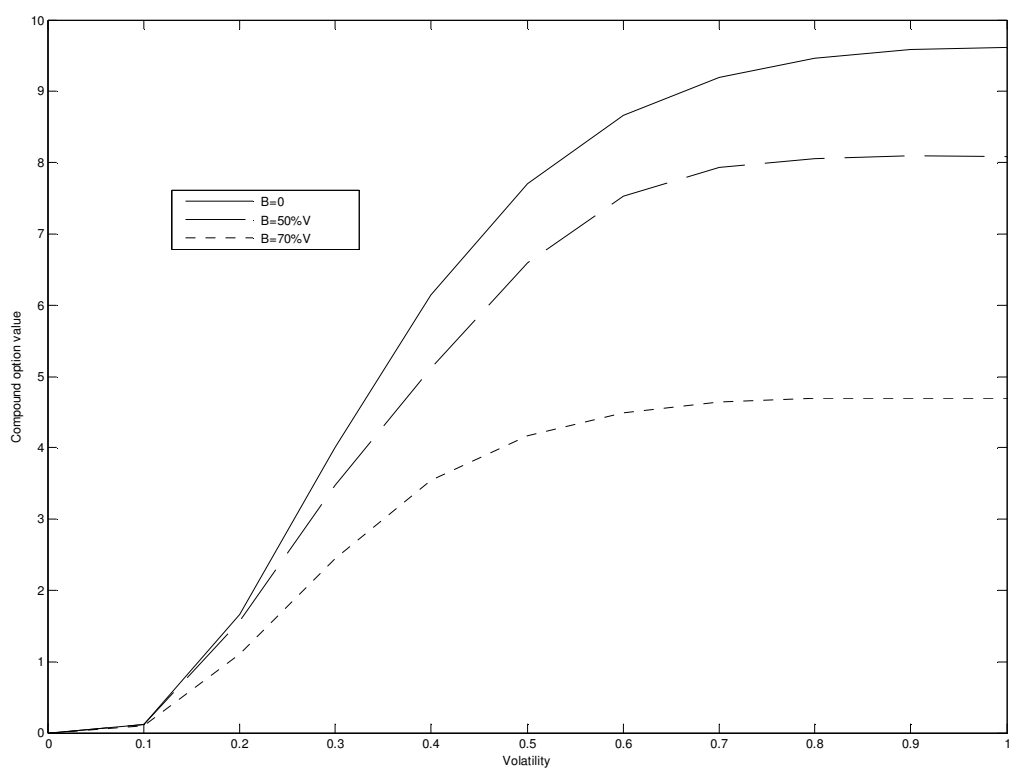




\section{Conclusion}

In this paper, we contribute to the literature by including a knock-out barrier option in a compound real option model to take account of immediate project failure, a so-called sudden death. While barrier options have become quite common in the financial option theory, applications of barrier-type options in a real investment setting are nonexistent so far. In our view, the possibility of sudden failure in large infrastructural investment projects or in the development of innovative technologies should be taken quite seriously. Inappropriately ignoring the possibility of sudden failure can have large and adverse consequences for investment decision making. While NPV computations may undervalue uncertain investment projects and unduly lead to project rejection, real option models that fail to account for the real possibility of intermediate project failure may lead to overvaluation and undue acceptance. Earlier attempts to deal with such phenomena use a Poisson process reflecting the probability that the project value jumps to zero or discrete failure probabilities at each stage of a compound option framework. We provide an alternative and elegant barrier approach to cope with this type of situations.

We apply the model to the case of hydrogen infrastructure development. Despite the theoretical attraction of a zero-emission hydrogen energy economy, the development of hydrogen energy infrastructure is often seen as an insurmountable technical and economic barrier to the use of hydrogen as an energy carrier. A future hydrogen transition relies on strategic planning and necessary investments; energy, economic and environmental analyses must be undertaken in concert with research in improved production, storage, and distribution technologies. To assist the transition, an adequate valuation approach is vital. Indeed, commercializing a new technology requires a revolutionary change from technological and market aspects; one might not anticipate the best path forward from the very beginning. No amount of planning and research can be trusted to reveal all contingencies and contingent probabilities from the start. For this reason, the use of a compound real option model where new information along the development path allows for reconsideration and reassessment is an attractive approach. Including an additional barrier option to reflect the possibility of project failure is appropriate in our view. However, it also makes valuation more complex as the project (option) value becomes path-dependent. Moreover, the extra boundary condition reduces the project value below that of the no barrier benchmark option. As such, decision making becomes more conservative and more often leads to rejection.

In our case study, we use a number of different external sources, of which the HyWays study is the most important one, to set the parameters in the model. Subsequently, we compute the project value for the hydrogen infrastructure project in the case of a barrier of 50 and 70 percent respectively of the 
NPV of the project cash flow in the full commercialization phase and benchmark it against valuation through an NPV model and a no-barrier real compound option model. We find that even for the least conservative valuation method, the no-barrier option model, no profitable business case can be made for the development of hydrogen as a sustainable transportation mode. This is consistent with earlier literature. Note though that all three real option models are much closer to the acceptance threshold imposed by the first phase investment costs than the NPV valuation. Subsequently, we provide some suggestive scenarios that plausible tax schedules can be designed to overcome the starting problems for hydrogen infrastructure development. A 25 percent excise duty discount is sufficient for a positive decision in the no-barrier framework. For the 50 percent barrier, one needs a discount between 25 and 50 percent, and for the 70 percent barrier a tax discount of somewhat over 50 percent. To the extent that sudden project failure would be predominantly caused by potential reversals in political support, a cheap way to make the development of hydrogen infrastructure - and other similar projects - more attractive would be to design credible long-term political commitments to this type of development. 


\section{References}

Adamson, K. and P. Pearson, 2000. Hydrogen and methanol: A comparison of safety, economics, efficiencies and emissions. Journal of Power Sources, 86(1-2), 548-555.

Agnolucci, P., 2007. Hydrogen infrastructure for the transport sector. International Journal of Hydrogen Energy, 32(15), 3526-3544.

Backhaus J. and I.G., Bunzeck, 2010. Planning and Permitting procedures for Hydrogen Refueling Stations: Analysis of Expected Lead Times for Hydrogen Infrastructure Build-up in the Netherlands.

Bowe, M. and D. Lee, 2004. Project Evaluating in the Presence of Multiple Embedded Real Options: Evidence From the Taiwan High-Speed Rail Project. Journal of Asian Economics, 15, 71-98.

Brandao, L.E.T. and E. Saraiva, 2008. The Option Value of Government Guarantees in Infrastructure Projects. Construction Management and Economics, 26(11), 1171-1180.

Broadie, M., Glasserman, P. and S. Kou, 1997. A Continuity Correction for Discrete Barrier Options. Mathematical Financial, 7(4), 325-348.

Brockman, P. and H.J. Turtle, 2003. A Barrier Option Framework for Corporate Security Valuation. Journal of Financial Ecnonomics, 67, 511-529.

CaFCP, 2008. Vision for Rollout of Fuel Cell Vehicles and Hydrogen Fuel Stations, California Fuel Cell Partnership Vision Document, USA: CA, 13p.

Cassimon, D., P.J. Engelen, L. Thomassen and M. Van Wouwe, 2004. The Valuation of a NDA Using a 6-fold Compound Option. Research Policy, 33(1), 41-51.

Cassimon, D., P.J. Engelen and V. Yordanov, 2011a. Compound Real Option Valuation with Phase-Specific Volatility: a Multi-phase Mobile Payments Case Study. Technovation, 31, 240-255.

Cassimon, D., M. De Backer, P.J. Engelen, M. Van Wouwe and V. Yordanov, 2011b. Incorporating Technical Risk into a Compound Option Model to Value a Pharma R\&D Licensing Opportunity. Research Policy, 40, 1200-1216.

Chang, L., Z. Li, D. Gao, H. Huang and W. Ni, 2007. Pathways for Hydrogen Infrastructure Development in China: Integrated Assessment for Vehicle Fuels and a Case Study of Beijing. Energy, 32(11), 2023-2037.

Damodaran, A., 2011. Financial Database, at http://pages.stern.nyu.edu/ adamodar.

Duffee, G.R., 1999. Estimating the Price of Default Risk. The Review of Financial Studies, 12(1), 197-226.

ECB, 2011. Annual Report of European Central Bank. www.ecb.int.

Elettra, A. and A. Rossella, 2003. A Generalization of the Geske Formula for Compound Options. Mathematical Social Sciences, 45(1), 75-82.

Esty, B. 2004. Why Study Large Projects? An Introduction to Research on Project Finance. European Financial Management, 10(2), 213-224.

Ekdunge, P. and M. Råberg, 1998. The Fuel Cell Vehicle Analysis of Energy Use, Emissions and Cost. International Journal of Hydrogen Energy, 23(5), 381-385.

Ford, D.N., D.M. Lander and J.J. Voyer, 2002. A Real Options Approach to Valuing Strategic Flexibility in Uncertain Construction Projects. Construction Management and Economics. 22(4), 343- 351.

Flyvbjerg, B., 2007a. Policy and Planning for Large-Infrastructure Projects: Problems, Causes, Cures. Environmental and Planning B: Planning and Design, 34, 578-597.

Flyvbjerg, B., 2007b. Cost Overruns and Demand Shortfalls in Urban Rail and Other Infrastructure. Transportation Planning and Technology, 30(1), 9-30. 
Flyvbjerg, B., M. Skamris Holm, and S. Buhl, 2005. How (In)accurate Are Demand Forecasts in Public Works Projects? Journal of the American Planning Association, 71(2), 131-146.

Gasafi, E., My. Reinecke, A. Kruse and L. Schebek, 2008. Economic Analysis of Sewage Sludge Gasification in Supercritical Water for Hydrogen Production. Biomass and Bioenergy. 32(12), 1085- 1096.

Geske, R., 1979. The Valuation of Compound Options. Journal of Financial Economics, 7(1), 63-81.

Guerrero, R., 2007. The Case for Real Options Made Simple. Journal of Applied Corporate Finance,19, 38-49.

Haryanto, A., S. Fernando, N.Murali. and S. Adhikari, 2005. Current Status of Hydrogen Production Techniques by Steam Reforming of Ethanol: A Review. Energy \& Fuels, 19, 2098-2106.

HyWays, 2008. Hydrogen Energy in Europe, Integrated Project under the $6^{\text {th }}$ FP of the European Commission, 2004-2007, www.hyways.de.

IEA, 2010. International Energy Agency, World Energy Outlook 2010, www.iea.org.

Jägle, A. J., 1999. Shareholder Value, Real Options, and Innovation in Technology-Intensive Companies. $R \& D$ Management, 29, 3.

Joffe, D., D. Hart and A. Bauen, 2004. Modelling of Hydrogen Infrastructure for Vehicle Refuelling in London. Energy Policy, 35, 5901-5908.

Kjærland, F, 2007. A Real Option Analysis of Investments in Hydropower- The Case of Norway. Journal of Power Sources, 131(1-2), 13-22.

Kou, S.G., 2003. On Pricing of Discrete Barrier Options. Statistica Sinica, 13(4), 955-964.

KPMG, 2011. International Corporate and Indirect Tax Survey 2011. www. kpmg.com

Lander, D.M. and G.E. Pinches, 1998. Challenges to the Practical Implementation of Modeling and Valuation Real Options. The Quarterly Review of Economics and Finance, 38, 537-567.

McGrath, R. G. and A. Nerkar, 2004. Real Options Reasoning and a New Look at the R\&D Investment Strategies of Pharmaceutical Firms. Strategic Management Journal, 25(1), 1-21.

Mercuri, R., A. Bauen and D. Hart, 2002. Options for Refueling Hydrogen Fuel Cell Vehicles in Italy. Journal of Power Sources, 106(1-2), 353-363.

Merton, R., 1973. The Rational Theory of Option Pricing. The Bell Journal of Economics and Management Science, 4 , 141-183.

Miller, R., and D. Lessard, 2000. The Strategic Management of Large Engineering Projects. Cambridge MA, USA, MIT Press.

Murthy Konda, N. V. S. N., N. Shah and N.P. Brandon, 2011. Optimal Transition Towards a Large-Scale Hydrogen Infrastructure for the Transport Sector: The Case for the Netherlands. International Journal of Hydrogen Energy, 36(8), 4619-4635.

Mulder, G., J. Hetland and G. Lenaers, 2007. Towards a Sustainable Hydrogen Economy: Hydrogen Pathways and Infrastructure. International Journal of Hydrogen Energy, 32(10-11), 1324-1331.

Newton, D. and A. Pearson, 1994. Application of Option Pricing Theory to R\&D. R\&D Management, 24, 83-89.

Ogden, J. M., 1999a. Developing an Infrastructure for Hydrogen Vehicles: A Southern California Case Study. International Journal of Hydrogen Energy, 24(8), 709-730.

Ogden, J.M., 1999b. Prospects for Building a Hydrogen Energy Infrastructure. Annual Review of Energy and the Environment, 24, 227-279. 
Reiss, A., 1998. Investment in Innovations and Competition: An Option Pricing Approach. The Quarterly Review of Economics and Finance, 3(2), 635-650.

Reisz, A.S. and C. Perlich, 2007. A Market-Based Framework for Bankruptcy Prediction. European Journal of Operational Research, 103, 83-94.

Rose, S., 1998. Valuation of Interacting Real Options in a Toll Road Infrastructure Project. The Quarterly Review of Economics and Finance, 38, 711-723.

Sandy Thomas, C. E., 2009. Transportation Options in a Carbon-constrained World: Hybrids, Plug-in Hybrids, Biofuels, Fuel Cell Electric Vehicles, and Battery Electric Vehicles. International Journal of Hydrogen Energy, 34(23), 92799296.

Schoots, K., G.J. Kramer and B.C.C. van der Zwaan, 2010. Technology Learning for Fuel Cells: An Assessment of Past and Potential Cost Reductions. Energy Policy, 38(6), 2887-2897.

Schulte, I., D. Hart and R. van der Vorst, 2004. Issues Affecting the Acceptance of Hydrogen Fuel. International Journal of Hydrogen Energy, 29(7), 677-685.

Schueler, A., 2007. Valuation of Companies in Financial Troubles: The Case of Eurotunnel. The Finsia Journal of Applied Finance, 2, 32-40.

Schwartz, E., 2004., Patents and R\&D as Real Options. Economic Notes, 33(1), 23-54.

Schwartz, E.S. and M. Moon, 2000. Evaluating R\&D Investments, In Brennan, M. and Trigeorgis, L. (eds), Project Flexibility, Agency and Competition. Oxford: Oxford University Press, 85-106.

Smit, Han T. J., 2003. Infrastructure Investment as a Real Options Game: The Case of European Airport Expansion. Financial Management, 32(4), 27-57.

Smit, R., M. Weeda and A. de Groot, 2007. Hydrogen Infrastructure Development in the Netherlands. International Journal of Hydrogen Energy, 32(10-11), 1387-1395.

Szyliowicz, J. and A. Goetz, 1995. Getting Realistic About Megaproject Planning: The Case of the New Denver International Airport. Policy Sciences, 28(4), 347-367.

Thomas, C. E., B. D. James and F. D. Lomax, 1998. Market Penetration Scenarios for Fuel Cell Vehicles. International Journal of Hydrogen Energy, 23(10), 949-966.

Trigeorgis, L., 2000. Real options and financial decision-making. Contemporary Finance Digest, 25-42.

van Benthem, A. A., G. J. Kramer and R. Ramer, 2006. An Options Approach to Investment in a Hydrogen Infrastructure. Energy Policy, 34(17), 2949-2963.

Vilanova, L., 2006. Financial Distress, Lender Passivity and Project Finance: The Case of Eurotunnel. Available at SSRN: http://ssrn.com/abstract=675304.

Weeds, H., 2002. Strategic Delay in a Real Options Model of R\&D Competition. Review of Economic Studies, 69(3), 729-747.

Wietschel, M., U. Hasenauer and A. Groot, 2006. Development of European Hydrogen Infrastructure Scenarios- $\mathrm{CO}_{2}$ Reduction Potential and Infrastructure Investment. Energy Policy, 34(11), 1284-1298.

Wong, H.Y., and Choi, T.W., 2009. Estimating default barriers from market information, Quantitative Finance, 9(2), 187-196.

Wooldridge, S.C., M.J. Garvin and Y.J. Cheah, 2002. Valuing Flexibility in Private Toll Road Development Analysis of the Dulles Greenway. The Journal of Structured Finance, 7(4), 25-36. 
Zhao, T., S. K. Sundararajan and C. Tseng, 2004. Highway Development Decision-Making under Uncertainty: A Real Options Approach. Journal of Infrastructure System, 10(1), 23-32. 


\section{Appendix A.}

Let $W_{\tau}$ be a standard Brownian motion. If we consider a function $f\left(x+W_{\tau}\right)$, then from Ito's lemma:

$$
d f\left(x+W_{\tau}\right)=\frac{\partial f\left(x+W_{\tau}\right)}{\partial W_{\tau}} d W_{\tau}+\frac{1}{2} \frac{\partial^{2} f\left(x+W_{\tau}\right)}{\partial W_{\tau}^{2}} d \tau
$$

If we integrate this equation with respect to $\tau$ then we obtain:

$$
f\left(x+W_{\tau}\right)=f(x)+\int_{0}^{\tau} \frac{\partial f\left(x+W_{s}\right)}{\partial W_{s}} d W_{s}+\frac{1}{2} \int_{0}^{\tau} \frac{\partial^{2} f\left(x+W_{s}\right)}{\partial W_{s}^{2}} d s
$$

Take an expectation on each side of the equation. Stochastic integral vanishes due to martingale property, and then we obtain:

$$
E\left[f\left(x+W_{\tau}\right)\right]=f(x)+\frac{1}{2} \int_{0}^{\tau} \frac{\partial^{2} E\left[f\left(x+W_{s}\right)\right]}{\partial x^{2}} d s
$$

Now we define the function

$$
A(\tau, x)=E\left[f\left(x+W_{\tau}\right)\right]
$$

Differentiating with respect to $\tau$, we see that $A(\tau, x)$ satisfies the heat equation

$$
\frac{\partial}{\partial \tau} A(\tau, x)=\frac{1}{2} \sigma^{2} \frac{\partial^{2}}{\partial x^{2}} A(\tau, x)
$$

and subject to the initial condition $A(0, x)=f(x)$, for fixed $\tau$, the random variable becomes $W_{\tau} \sim N(0, \sigma \sqrt{\tau})$. We can therefore rewrite the solution [A.4] as $A(\tau, x)=E[f(x+\sigma \sqrt{\tau} Z)]$, where $Z$ is a standard $N(0,1)$ random variable.

Explicitly writing out the expectation we have:

$$
A(\tau, x)=\frac{1}{\sqrt{2 \pi}} \int_{-\infty}^{\infty} f(x+\sigma \sqrt{\tau} \xi) e^{-\frac{1}{2} \xi^{2}} d \xi
$$

Following by the next step, the multi-dimensional Ito rule is a straight-forward generalization of the one-dimensional case. If $C(t, V)$ is the value of a derivative at time $t$ which expires at time $T$, equation [2] must also satisfy the partial differential equation:

$$
\frac{\partial C(t, V)}{\partial t}=r C(t, V)-r V \frac{\partial C(t, V)}{\partial V}-\frac{1}{2} \sigma V^{2} \frac{\partial^{2} C(t, V)}{\partial V^{2}}
$$

Now in order to reduce the above PDE to the heat equation, we will make a series of sophisticated transformations. Set $C(t, V)=\alpha(\tau, V)$, where $\tau=T-t$ is a new time coordinate which still runs over the same interval $[0, T]$ as $t$, but in the opposite direction. We need to reverse the direction of time, so that the terminal payout of the option becomes the initial condition for the heat equation. The time derivatives of $C(t, V)$ and $\alpha(\tau, V)$ are related by 
$\frac{\partial C}{\partial t}=-\frac{\partial \alpha}{\partial \tau}$

while all the other derivatives remain the same. Hence the

$\frac{\partial \alpha}{\partial \tau}=\frac{1}{2} \tilde{\sigma}^{2} V^{2} \frac{\partial^{2} \alpha}{\partial V^{2}}-r \alpha+r V \frac{\partial \alpha}{\partial V}$

This equation now has the "right" sign for the time derivative, and has the initial condition

$$
\begin{aligned}
\alpha\left(0, V_{T}\right) & =C\left(T, V_{T}\right) \\
& =F\left(T, V_{T}\right)
\end{aligned}
$$

We now want to eliminate the $r \alpha$ term. We can do this by introducing a "discount factor" $e^{-r \tau}$ explicitly into the equation. Set $\alpha(\tau, V)=\beta(\tau, V) e^{-r \tau}$. The time derivative is then

$\frac{\partial \alpha}{\partial \tau}=\left(\frac{\partial \beta}{\partial \tau}-r \beta\right) e^{-r \tau}$

and hence equation [A.11] can be written as

$\frac{\partial \beta}{\partial \tau}=\frac{1}{2} \tilde{\sigma}^{2} V^{2} \frac{\partial^{2} \beta}{\partial V^{2}}+r V \frac{\partial \beta}{\partial V}$

To proceed further, we want to write the equation in terms of the operator $V \partial / \partial V$. This can be easily accomplished by rearranging the second order term,

$$
\frac{\partial \beta}{\partial \tau}=\frac{1}{2} \tilde{\sigma}^{2} V \frac{\partial}{\partial V}\left(V \frac{\partial \beta}{\partial V}\right)+\left(r-\frac{1}{2} \tilde{\sigma}^{2}\right) V \frac{\partial \beta}{\partial V}
$$

We can simplify the operator $V \partial / \partial V$ by defining the new variable $Y=\ln V$, and noting that

$$
V \frac{\partial}{\partial V}=\frac{\partial}{\partial Y}
$$

If we then introduce the new function $\gamma(\tau, Y)=\beta(\tau, V)$, we see that the differential equation [A.13] becomes

$\frac{\partial \gamma}{\partial \tau}=\frac{1}{2} \tilde{\sigma}^{2} \frac{\partial^{2} \gamma}{\partial Y^{2}}+\left(r-\frac{1}{2} \tilde{\sigma}^{2}\right) \frac{\partial \gamma}{\partial Y}$

Define $X=Y+\left(r-\frac{1}{2} \tilde{\sigma}^{2}\right) \tau$, and set $A(\tau, X)=\gamma(\tau, Y)$. The partial derivative of $\gamma$ with respect to $\tau$ is then given by

$$
\begin{aligned}
\frac{\partial \gamma}{\partial \tau} & =\frac{\partial A}{\partial \tau}+\frac{\partial A}{\partial X} \frac{\partial X}{\partial \tau} \\
& =\frac{\partial A}{\partial \tau}+\frac{\partial A}{\partial X}\left(r-\frac{1}{2} \tilde{\sigma}^{2}\right)
\end{aligned}
$$

In this way, we obtain the heat equation identical to equation [A.5]

Now we would like to solve the option price $C\left(t, V_{t}\right)$ subject to the terminal condition $C\left(T, V_{T}\right)=F\left(V_{T}\right)$ 
where $F\left(V_{T}\right)$ is a prescribed function, that is, the payoff function of the derivative. As noted earlier, $t=T$ corresponds to $\tau=0$, which is why the terminal payoff function of the derivative is actually an initial condition for $A(\tau, x)$. If we follow through the various transformations made above, then we see that the relation between $C\left(t, V_{t}\right)$ and $A(\tau, x)$ is

$$
\begin{aligned}
C\left(T, V_{T}\right) & =\alpha\left(T-t, V_{t}\right) \\
& =\beta\left(T-t, V_{t}\right) e^{-r(T-t)} \\
& =\gamma\left(T-t, \log V_{t}\right) e^{-r(T-t)} \\
& =A\left(T-t, \log V_{t}+\left[r-\frac{\sigma^{2}}{2}\right][T-t]\right) e^{-r(T-t)}
\end{aligned}
$$

In particular the derivative payoff function can be written as

$$
\begin{aligned}
F\left(V_{T}\right) & =C\left(T, V_{T}\right) \\
& =A\left(0, \log V_{T}\right)
\end{aligned}
$$

Hence the initial condition on $A(\tau, x)$ at $\tau=0$ is

$A(0, x)=F\left(e^{x}\right)$

without the barrier, a call option has

$A(0, x)=\max \left(0, e^{x}-I\right)$

Applied equation [A.6] for the solution of the heat equation with the initial condition $A(0, x)=F\left(e^{x}\right)$,

$A(\tau, x)=\frac{1}{\sqrt{2 \pi}} \int_{-\infty}^{\infty} F\left(e^{x+\sigma \sqrt{\tau \xi}}\right) e^{-\frac{1}{2} \xi^{2}} d \xi$

Using this value of $A(\tau, x)$ and the transformation [A.22] we can then write the option price as

$$
\begin{aligned}
C^{\prime}(t, V) & =A\left(T-t, \log V_{t}+\left[r-\frac{\sigma^{2}}{2}\right][T-t]\right) e^{-r(T-t)} \\
& =\frac{e^{-r(T-t)}}{\sqrt{2 \pi}} \int_{-\infty}^{\infty} F\left(V_{t} e^{r(T-t)+\sigma \sqrt{\tau} \xi-\frac{1}{2} \sigma^{2} \tau}\right) e^{-\frac{1}{2} \xi^{2}} d \xi
\end{aligned}
$$

Taking into the down-and-out barrier $B$, the payoff $C^{\prime}(t, V)$ is zero for all $V$ below the strike $I$; this translates into for $V<\log \left(\frac{\mathrm{I}}{\mathrm{B}}\right)$. We set the barrier below the strike to ensure that $\log \left(\frac{I}{B}\right)>0$.

Let $V=B e^{x}$ and $k=r / \frac{1}{2} \sigma^{2}$.

Barrier option value can be written as $C(t, V)=B \cdot e^{-\frac{1}{2}(k-1)-\frac{1}{4}(k+1)^{2} \tau} U(t, x)$

In these new variables the barrier transforms to the point $x=0$, and the barrier option problem becomes 
$\frac{\partial U}{\partial \tau}=\frac{\partial^{2} U}{\partial x^{2}}$

with $U(0, x)=\max \left(e^{\left(\frac{1}{2}(k+1) x\right.}-e^{\exp \left(\frac{1}{2}(k-1) x\right.}, 0\right)$, for $x>0$, with $U(0, t)=0$.

we can now put the pieces together to show that the barrier option value is

$C(t, V)=V N\left(d_{1}\right)-I \cdot e^{-r(T-t)} N\left(d_{2}\right)-V \cdot\left(\frac{B}{V}\right)^{k+1} N\left(d_{3}\right)+I \cdot e^{-r(T-t)}\left(\frac{B}{V}\right)^{k-1} N\left(d_{4}\right)$

which corresponds to Equation [9] in the text. 


\section{Appendix B Structure of the cash flow model}

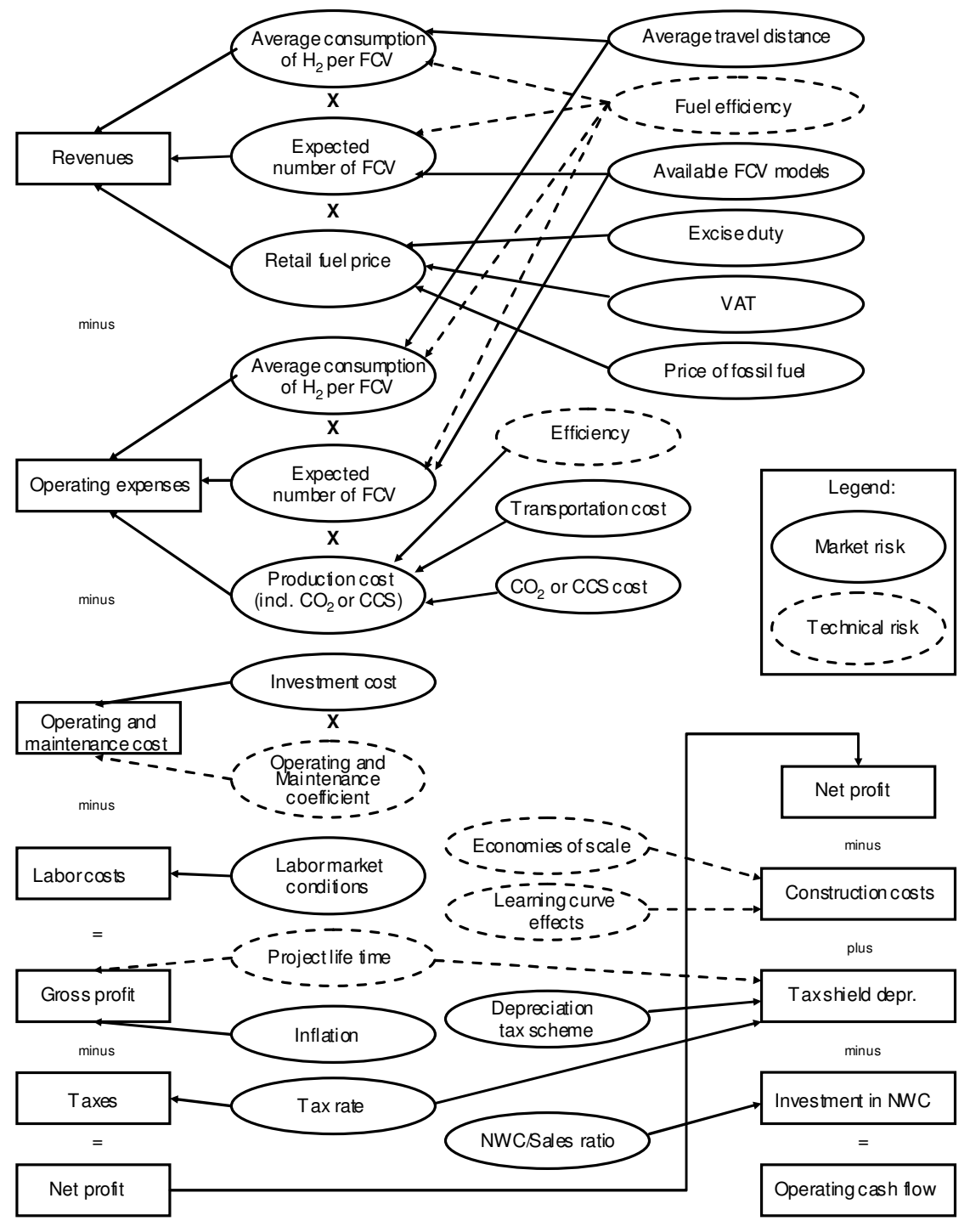




\section{Appendix C. Company descriptions of a set of comparable firms}

Hydrogenics Corporation designs, develops, and manufactures hydrogen generation products based on water electrolysis technology and fuel cell products based on proton exchange membrane technology in Canada and internationally. The company's OnSite Generation segment develops and sells products for industrial gas, hydrogen fueling, and renewable energy storage markets. This segment's product line comprises HySTAT Hydrogen Stations that provide on-site supply of hydrogen for various hydrogen applications, including vehicle fueling, distributed power, and various industrial processes; and provides spare parts and services. Its Power Systems segment develops products for stationary and motive power applications. This segment's product line consists of HyPM fuel cell products, such as HyPM fuel cell power modules, HyPXTM fuel cell power pack, and integrated fuel cell systems; and offers engineering development services. The company serves industrial gas companies, industrial end users, oil and gas companies, and utilities, as well as original equipment manufacturers, systems integrators, and end users. It offers its products through direct sales force, as well as through a network of distributors. Hydrogenics Corporation was founded in 1988 and is headquartered in Mississauga, Canada.

Ballard Power Systems Inc. engages in the design, development, manufacture, sale, and service of fuel cell products for motive and stationary power markets primarily in the United States, Canada, the United Kingdom, and Germany. It operates in three segments: Fuel Cell Products, Contract Automotive, and Material Products. The Fuel Cell Products segment provides fuel cell products and services for material handling and bus, back-up power, supplemental power, and distributed generation applications. The Contract Automotive segment provides contract technical and manufacturing, testing, and other engineering services. The Material Products segment provides carbon fiber material products principally for automotive applications and gas diffusion layer material for fuel cell products. Ballard Power has strategic partnerships with Dantherm Power A/S, which develops clean energy backup power through utilization of the company's hydrogen fuel cell technology; and Automotive Fuel Cell Cooperation Corp. that develops fuel cell products for the automotive fuel cell market. The company was founded in 1979 and is headquartered in Burnaby, Canada.

FuelCell Energy, Inc., together with its subsidiaries, engages in the development, manufacturing, and sale of high temperature fuel cells for clean electric power generation primarily in South Korea, the United States, Germany, Canada, and Japan. The company offers proprietary carbonate Direct FuelCell Power Plants that electrochemically produce electricity from hydrocarbon fuels, such as natural gas and biogas. Its fuel cells operate on a range of hydrocarbon fuels, including natural gas, renewable biogas, propane, methanol, coal gas, and coal mine methane. The company also develops carbonate fuel cells, planar solid oxide fuel cell technology, and other fuel cell technologies. It provides its products to universities; manufacturers; mission critical institutions, such as correction facilities and government installations; hotels; and natural gas letdown stations, as well as to customers who use renewable biogas for fuel, including municipal water treatment facilities, breweries, and food processors. The company was founded in 1969 and is headquartered in Danbury, Connecticut.

Plug Power Inc., an alternative energy technology provider, involves in the design, development, commercialization, and manufacture of fuel cell systems for the industrial off-road markets and stationary power markets worldwide. It develops and sells a range of fuel cell systems comprising hydrogen-fueled Proton Exchange Membrane (PEM) systems. The company's product line includes PEM GenDrive power unit for sale on commercial terms for industrial off-road consisting of forklift or material handling applications, with a focus on multi-shift high volume manufacturing and high throughput distribution sites. It sells its products to business, industrial, and government customers through direct product sales force, original equipment manufacturers, and their dealer networks. The company was founded in 1997 and is headquartered in Latham, New York.

Source: Yahoo! Finance (2011) 
Table C1 Stylized Corporate Statistics

\begin{tabular}{|l|r|r|r|r|}
\hline Company $^{\mathrm{c}}$ & Hydrogenics Corp. & $\begin{array}{r}\text { Ballard Power } \\
\text { Systems Inc. }\end{array}$ & $\begin{array}{r}\text { FuelCell Energy, } \\
\text { Inc. }\end{array}$ & $\begin{array}{r}\text { Plug Power } \\
\text { Inc. }\end{array}$ \\
\hline Trading venue & NASDAQ & NASDAQ & NASDAQ & NASDAQ \\
\hline Ticker code & HYGS & BLDP & FCEL & PLUG \\
\hline $\begin{array}{l}\text { Market } \\
\text { capitalization }\end{array}$ & $\$ 37.53$ million & $\$ 113.92$ million & $\$ 128.66$ million & $\$ 43.52$ million \\
\hline Long-term debt $^{\mathrm{b}}$ & $\$ 0$ million & $\$ 27,090$ million & $\$ 12,411$ million & $\$ 0$ million \\
\hline $\begin{array}{l}\text { Equity } \\
\text { b }\end{array}$ & $\$ 17,626$ million & $\$ 128,288$ million & $\$ 8,350$ million & $\$ 42,913$ \\
million \\
\hline $\begin{array}{l}\text { Number of } \\
\text { employees }\end{array}$
\end{tabular}

Legend: ${ }^{a}$ As of October 2011, ${ }^{b}$ As of Fiscal Year 2010, ${ }^{c}$

Source: Yahoo!Finance (2011) 